\title{
PENGARUH PEMBERIAN PASTA IKAN BELUT TERHADAP PERTUMBUHAN DAN SINTASAN PADA LARVA IKAN LELE DUMBO (Clarias gariepinus)
}

\author{
Oleh : \\ Yenni Nuraeni dan Ade Sunaryo \\ Dosen Jurusan Penyuluhan Perikanan Sekolah Tinggi Perikanan
}

\begin{abstract}
ABSTRAK
Phase larva adalah phase yang kritis dan rentan terhadap kematian yang disebakan oleh ketersediaan pakan dan faktor media pemeliharaannya. Pada tingkat larva, lele dumbo perlu diberikan pakan yang mudah dicerna sehingga pakan yang diberikanan dapat dicerna dengan baik. Dalam penelitian ini dipelihara larva ikan lele dumbo sebanyak 900 ekor di dalam 9 buah hapa yang berukuran $60 \mathrm{~cm} \times 40 \mathrm{~cm} \times 40 \mathrm{~cm}$ yang ditempatkan di tengah kolam plastik trepal ukuran $4 \mathrm{~m} \times 3 \mathrm{~m} \times 0,5 \mathrm{~m}$ plastik dengan kedalaman air $20 \mathrm{~cm}$. Pergantian air dilakukan setiap 7 hari sekali sebanyak $20 \%$ volume air pemeliharaannya.

Lama waktu uji pemeliharaan larva benih lele dumbo ini selama 21 hari, oksigen berasal dari hasil difusi melalui pemasangan pompa aerasi . Larva yang dipelihara diberi pakan yang berbeda berupa larva Daphnia sp yang terlebih dahulu disaring dengan saringan halus, cacing tubifex diberikan dalam bentuk segar dan pasta ikan belut yang dibentuk bulat dengan diameter $5 \mathrm{~mm}$ dengan frekuensi pemberian $3 \mathrm{kali} / \mathrm{hari}$ secara adlibitum.

Hasil perhitungan ANOVA pada akhir penelitian menunjukkan bahwa pertumbuhan harian dan kelulushidupan atau sintasan menghasilkan $\mathrm{F}$ hitung $>$ $\mathrm{F}$ table 0,01 yang berarti bahwa pemberian pakan jenis ekstrak ikan belut memberikan perbedaan yang sangat nyata pada laju pertumbuhan harian (SGR) sintasan (SR) larva ikan lele dumbo, sintasan tertinggi dicapai pada perlakuan P2 (88,34\%) dengan pakan pasta ikan belut jika dibandingkan pada perlakuan pakan Daphnia P1(68,75\%) dan cacing tubifex sebagai kontrol P3(72,50\%).
\end{abstract}

Kata Kunci : Larva lele dumbo, daphnia sp, tubifex sp, pasta ikan belut, sintasan dan pertumbuhan harian

\section{PENDAHULUAN}

Kendala dalam meningkatkan produksi benih ikan lele dumbo salah satunya adalah rendahnya sintasan larva yang baru mencapai $50 \%$.
Rendahnya sintasan tersebut disebabkan karena masih tingginya mortalitas pada phase larva terutama setelah menetas hingga mencapai ukuran 1-2 cm baik di dalam bak ataupun akuarium. Terjadinya 
mortalitas yang tinggi pada phase larva salah satunya disebabkan oleh ketidasesuaian manajemen pakan baik dari kualitas maupun kuantitasnya yang diberikan kepada larva karena ketersediannya terbatas dan juga mahal harganya. Selain hal tersebut ada juga pakan alami yang sering digunakan pada stadia larva yang dapat berperan sebagai carier pathogen (misalnya cacing tubifex) sehingga ada kalanya dapat menyebabkan penurunan tingkat kesehatan larva.

Upaya yang perlu dilakukan adalah dengan penyediaan pakan yang tepat dan tersedia waktu dengan tingkat kesesuaian yang baik untuk diberikan kepada larva ikan lele dumbo.

Hasil penelitian diharapkan ada solusi akan alternatip dalam penyediaan pakan yang dapat tersedia setiap waktu dengan tingkat kebersihan yang aman diberikan kepada larva ikan lele dumbo atau bebas pathogen.

Dalam penelitian ini dilakukan uji coba pemberian pasta ikan belut dan daphnia pada larva usia 3 hari setelah menetas dengan kontrol berupa larva ikan lele dumbo yang diberi cacing.

\section{Tujuan}

1. Meningkatkan prosentase sintasan pada phase larva dari $50 \%$ s.d. $70 \%$

2. Membuat alternatif penyediaan jenis pakan alami untuk larva lele dumbo

\section{Hyphothesis}

$\mathrm{HO}$ : Ada pengaruh pemberian pakan pasta belut pada pertmbuhan dan sintasan larva lele dumbo
$\mathrm{H} 1$ : Tidak ada pengaruh perlakuan pemberian pakan pasta belut pada pertumbuhan dan sintasan larva lele dumbo

\section{METODE PENELITIAN}

\section{Waktu dan Tempat}

Penelitian dimulai bulan Juli s.d. Agustus 2010 di Hatchery STP Jurusan Penyuluhan Perikanan Bogor Jawa Barat.

1. Hewan Uji :

Hewan uji yang digunakan untuk kegiatan penelitian ini adalah larva ikan lele Dumbo umur 3 hari (pasca 3 hari menetas) berasal dari pemijahan sendiri.

2. Pakan Uji :

Pasta ikan belut, daphnia sp, dan cacing tubifex sebagai kontrol

Pakan cacing tubifex berasal dari sekitar wilayah penelitian. Pasta ikan belut berasal dari olahan daging ikan belut dengan formulasi sederhana tanpa tambahan bahan lainnya.

a. Prosedur Penelitian

Penelitian yang dilaksanakan meliputi beberapa tahapan kegiatan sebagai berikut :

1. Penyiapan larva lele dumbo umur 3 hari

2. Penyiapan pakan uji

3. Uji Pemeliharaan larva lele dumbo yang diberi pakan alami jenis dapnia sp dan cacing tubifex sebagai kontrolnya, dan pasta belut sebagai tujuan bahan uji pada penelitian ini.

\section{Desain Penelitian}

Rancangan percobaan dalam penelitian ini adalah RAL (Rancangan 
Acak Lengkap). Rancangan percobaan ini terdiri dari dan 3 perlakuan 3 ulangan yaitu sebagai berikut :

Perlakuan (P1) : Daphnia 3 ulangan (P2) : Pasta Belut 3 ulangan. Kontrol (P3) : Cacing Tubifex 3 ulangan

\section{Uji Pemeliharaan larva}

Dalam penelitian ini dipelihara larva ikan lele dumbo sebanyak 900 ekor di dalam happa yang berukuran $60 \times 40 \times 40 \mathrm{~cm}$ dengan kedalaman air $20 \mathrm{~cm}$. Pasokan oksigen berasal dari hasil difusi melalui pemasangan pompa aerasi . Larva yang dipelihara diberi pakan yang berbeda berupa Daphnia sp, pasta ikan belut, dengan kontrol cacing tubifex. Daphnia yang diberikan adalah larva yang baru menetas terlebih dahulu disaring dengan scopnet halus, pasta belut dibentuk bulat-bulat dengan diameter $5 \mathrm{~mm}$, sedangkan cacing tubifex diberikan langsung dalam keadaan segar. Pergantian air dilakukan setiap 7 hari sekali sebanyak $20 \%$ dari volume air pemeliharaan. Adapun frekuensi pemberian $3 \mathrm{kali} / \mathrm{hari}$ pada setiap pukul $06.00,13.00$ dan 19.30 secara adlibitum.

\section{Parameter yang diukur \\ Kualitas Air}

Parameter Kualitas Air yang diukur pada penelitian ini terdiri dari (DO, $\mathrm{pH}, \quad \mathrm{NH} 3$, Nitrit, Nitrat )

\section{Pertumbuhan dan Sintasan}

Pertumbuhan dan sinatasan akan diukur dengan menggunakan rumus pertumbuhan harian dan sintasan sebagai berikut : Pertumbuhan Harian (Formula De Silva dan Anderson, 1995) :

$$
\begin{aligned}
& \mathrm{SGR}=\frac{\ln (\mathrm{W} 2)-\ln (\mathrm{W} 1)}{\mathrm{t} 2-\mathrm{t} 1} \times 100 \% \\
& \ln \mathrm{W} 1=\text { Berat biomas awal } \\
& \ln \mathrm{W} 2=\text { Berat biomas akhir } \\
& \mathrm{t} 1 / \mathrm{t} 2=\text { waktu } \\
& \text { Sintasan } \\
& \mathrm{SR}=\mathrm{N} 2 / \mathrm{N} 1 \times 100 \% \\
& \mathrm{SR}: \text { Survival Rate } \\
& \mathrm{N} 1: \text { Jumlah individu awal } \\
& \mathrm{N} 2: \text { Jumlah individu akhir }
\end{aligned}
$$

Analisis hasil penelitian

Analisis hasil penelitian diuji dengan ANOVA untuk melihat apakah ada perbedaan yang nyata atau berbeda nyata dari seluruh pengaruh perlakuan pemberian pakan pasta belut pada larva ikan lele dumbo terhadap pertumbuhan dan sintasan yang dibandingkan dengan larva yang diberi dapnia sp atau cacing tubifex sebagai control selama kegiatan penelitian dilaksanakan.

\section{HASIL DAN PEMBAHASAN}

a. Pertumbuhan (SGR/ Spesific Growth Rate)

Hasil penelitian pada perlakuan 2 (dua) perlakuan dan 1 kontrol jenis pakan dapat dilihat pada Tabel 1. Hasil perhitungan ANOVA laju pertumbuhan berat spesifik menghasilkan $F$ hitung $>\mathrm{F}$ table 0,01 yang berarti bahwa pemberian pakan jenis ekstrak ikan belut memberikan perbedaan yang sangat nyata pada laju pertumbuhan berat spesifik larva ikan lele dumbo, yaitu pada perlakuan P2 dengan pakan alami ekstrak pasta ikan belut jika dibandingkan pada perlakuan P1 dan P3 (kontrol). 
Tabel 1. Data rata-rata laju pertumbuhan spesifik dan pertumbuhan panjang mutlak larva ikan Lele Dumbo hasil perlakuan 3 (tiga) jenis pakan alami yang berbeda.

\begin{tabular}{|l|l|l|}
\hline Perlakuan & SGR \pm SD $(\%$ BT/Hari) & Lm \pm SD $(\mathrm{mm})$ \\
\hline P1 ( Daphnia) & $11,7078 \pm 0,3551^{\mathrm{a}}$ & $7,2250 \pm 0,53771^{\mathrm{a}}$ \\
\hline P2 (Pasta Belut) & $15,9522 \pm 0,2747^{\mathrm{b}}$ & $15,1250 \pm 0,3500^{\mathrm{b}}$ \\
\hline P3 (Tubifex ) & $14,7078 \pm 0,2125^{\mathrm{c}}$ & $12,7750 \pm 0,8021^{\mathrm{c}}$ \\
\hline
\end{tabular}

Ket : Superskrip yang berbeda pada kolom yang sama menunjukan adanya perbedaan yang nyata $(p<0,05)$

b. Sintasan (Survival Rate) Data sintasan larva ikan lele dumbo yang hidup pada akhir penelitian terdapat pada

Tabel 2. Hasil perhitungan ANOVA kelulushidupan atau sintasan menghasilkan $F$ hitung $>\mathrm{F}$ table 0,01 yang berarti bahwa pemberian pakan jenis ekstrak ikan belut memberikan perbedaan yang sangat nyata pada laju sintasan larva ikan lele dumbo, yaitu pada perlakuan P2 dengan pakan alami ekstrak pasta ikan belut jika dibandingkan pada perlakuan P1 dan P3.

Tabel 2. Data Sintasan larva ikan Lele Dumbo (\%)

\begin{tabular}{|l|l|}
\hline \multicolumn{1}{|c|}{ Perlakuan } & SR ( \% Sintasan) \\
\hline P1 ( Daphnia) & $68,75 \pm 2,0967^{\mathrm{a}}$ \\
\hline P2 (Pasta Belut) & $88,34 \pm 2,3570^{\mathrm{b}}$ \\
\hline P3 (Tubifex) & $72,50 \pm 4,1670^{\mathrm{c}}$ \\
\hline
\end{tabular}

Ket : Superskrip yang berbeda pada kolom yang sama menunjukan adanya perbedaan yang nyata $(p<0,05)$

Larva ikan Lele Dumbo yang diberi perlakuan pakan alami yang berbeda mengalami peningkatan seiring bertambahnya waktu pemeliharaan, demikian juga dengan laju pertumbuhannya. Laju pertumbuhan berat paling tinggi pada larva ikan lele dumbo dengan perlakuan pasta ikan belut $88,34 \%$. Hal tersebut menunjukan bahwa pasta ikan belut dapat diterima oleh larva ikan lele yang berumur 3 (tiga) hari sebagai pakan alami awal setelah kuning telur habis dan larva lele sudah memerlukan pakan alternatif. Sehingga dengan demikian maka perlu adanya penelitian lanjutan tentang tingkat perbedaan kecernaan atau kemudahan mencerna pakan alami, karena penelitian kaji terap ini baru dilakukan dan belum ada penelitian yang dilakukan sebelumnya. Menurut Praptokardiyo (2006) bahwa pakan adalah merupakan fungsi produksi (f(X2), diperkirakan bahwa pasta ikan belut mudah dicerna oleh larva ikan lele dumbo. 
Perlakuan ke P2 menggunakan pakan alami cacing tubifex yang menunjukan sintasan dan pertumbuhan bobot spesifik pada hasil penelitian ini dapat dikatakan sudah baik dengan sintasan $72,50 \pm 4,1670 \mathrm{c}$ $(72,50 \%)$ karena cacing adalah termasuk jenis pakan alami yang disukai oleh ikan lele dumbo. Hal tersebut dikarenakan ikan lele dumbo adalah jenis ikan yang sebagian besar akan menempati wilayah dasar kolam dengan jenis pakan alami detritus (Viveen, 1986; Zonneveld, 1987).

Cacing tubifex spp, memiliki serat kasar yang rendah yaitu $0,29 \%$ sehingga disukai oleh dan mudah dicerna oleh larva ikan lele dumbo yang nantinya berpengaruh terhadap pertumbuhan (Ayinla and Akande, 1988).

Perlakuan P1 menggunakan pakan alami jenis Daphnia spp, menunjukan pertumbuhan dan dan sintasan terendah yaitu $68,75 \pm 2,0967$ a $(68,75 \%)$ jika dibandingkan dengan perlakuan pasta ikan belut dan perlakuan P3 cacing tubifex spp pada P2. Ini kemungkinan terjadi karena ukuran jasad renik daphnia spp tidak mudah dicerna karena mengandung cangkang lapisan kulit yang juga ikan atau udang memerlukan energi atau enzym khusus dalam melakukan percernaan, jika percernaan terhambat maka penyerapan energi dari asupan pakan akan terhambat dan mempengaruhi aktivitas metabolisme dalam tubuh (Sunaryo and Schwark,2006).

c. Paramater Kualitas Air

Parameter kualitas air yang banyak berperan dalam pertumbuhan dan kelulus hidupan atau sintasan organisme air diantaranya yaitu suhu, $\mathrm{pH}$, oksigen terlarut dan amonika. Selama penelitian dilaksanakan suhu air berkisar antara $22-28^{\circ} \mathrm{C}$. Pada kisaran suhu tersebut larva ikan lele dapat hidup dengan baik (Purnomo, 2006) yang menyatakan bahwa ikan lele dumbo dapat hidup pada kisaran suhu $20^{\circ} \mathrm{C}$, untuk suhu optimum antara $25-28^{\circ} \mathrm{C}$. Derajat keasaman $(\mathrm{pH})$ selama penelitian berkisar antara $6-7$, kisaran $\mathrm{pH}$ ini sesuai dengan pernyataan Rukmana (2003), bahwa $\mathrm{pH}$ yang ideal untuk pemeliharaan ikan lele dumbo adalah 6,5-8,0.

Konsentrasi oksigen terlarut pada penelitian ini berkisar antara 3 ppm - 5 ppm. Tingkat kelarutan oksigen tersebut sudah memenuhi syarat untuk pemeliharaan larva ikan lele dumbo yaitu harus $3 \mathrm{ppm}$ (Rukmana, 2003). Amoniak merupakan gas buangan hasil metabilisme ikan dari perombakan protein, baik dari feces maupun sisa pakan atau sisa metabolisme (Lesmana, 2001). Adapun hasil penelitian bahwa konsentrasi amoniak berkisar antara 0,003-0,005 ppm, Rukmana (2003) menyatakan bahwa amoniak pada pemeliharaan larva lele 
dumbo harus kurang dari 0,005 ppm.

\section{KESIMPULAN DAN SARAN}

\section{Kesimpulan}

Hasil sintasan pada penelitian pakan alami jenis pasta ikan belut dengan sintasan $88,34 \%$ sebagai hasil penelitian tertinggi sintasannya , pakan jenis tubifex spp $72,50 \%$ dan pakan jenis daphnia spp $68,75 \%$. Sedangkan pertumbuhan berat spesifik tercapai pada perlakuan P2 yaitu dengan SGR 15,9522 \% BT/hari.

\section{Saran}

Menyimak hasil penelitian maka pasta ikan belut disarankan sebagai prototipe pakan alami alternatif untuk larva ikan lele dumbo umur 3 (tiga) hari setelah kuning telur sebagai sumber energi larva habis dapat menggunakan pasta ikan belut sebagai pakan alami. Perlu dilakukan penelitian lanjutan untuk mengetahui tingkat kecernaan pasta belut oleh larva benih ikan lele. Jika dikaji secara ekonomis biaya pengadaan pasta ikan belut harganya masih dapat dikatakan mahal dibandingkan jenis pakan alami tubifex spp ataupun daphnia spp, oleh karena itu perlu ada penelitian lanjutan tentang tingkat efisiensi penggunaan pasta ikan belut dengan menguji campuran bahan baku pakan ikan yang tepat sebagai bahan tambahan campuran pembuatan pasta ikan belut sehingga didapat biaya yang murah, efektif dan efisien dalam pemakainnya.

\section{DAFTAR PUSTAKA}

Ayinla, O.A. and GR. Akande, 1988. Growth Responses of Clarias gariepinus (Burchell 1822) on Silage - Based diets. Nrg Inst. Oceanogr and Mar. Res. Tech. Paper $37: 19$

Lesmana DS. 2001. Kualitas Air untuk ikan Hias Air Tawar. Penebar Swadaya Jakarta. Hal 23-29

Praptokardyo K, Wellem M. 2008. Diktat Pengelolaan Produksi Budidaya Perairan Payau/Laut. Bogor.

Praptokardyo K, Wellem M. 2008. Diktat Pengembangan Perikanan Budidaya. Bogor.

Rukmana, 2003. Budidaya Ikan Lele Dumbo (Calrias gariepinus). Penebar Swadaya Jakarta. 54 Hal

Sunaryo and Schwark. 2006. Effects of Substrate and Shelter on Survival Rate and Growth Rate Post Larvae of Giant Freshwater Prawn (Macrobrachium rosenbergii de Man).47 pages.

Vivien, W.J.A.R 1986 : Zonneveid, 1987, Practicel Manual For The Culture of The African Catfish. Directorat General International Cooperation of Ministry of Foreign Affairs, the Haqe, the Nederlands $94 \mathrm{pp}$ 
Zonneveld, N.,Huisman E.A dan Boon, J.H. 1991. Prinsip-prinsip

Budidaya Ikan. Gramedia

Pustaka Utama, Jakarta. 